\title{
COMPACTION CAUSED BY MECHANIZED OPERATIONS IN A RED- YELLOW LATOSOL CULTIVATED WITH COFFEE OVER TIME
}

\author{
Compactação causada pelas operações mecanizadas em um Latossolo Vermelho-Amarelo \\ cultivado com cafeeiros ao longo do tempo
}

Paula Cristina Caruana Martins ${ }^{1}$, Moacir de Souza Dias Junior², Maria Luiza de Carvalho Andrade ${ }^{1}$, Paulo Tácito Gontijo Guimarães ${ }^{3}$

\begin{abstract}
The main source of soil structure degradation in coffee plantation is the machinery traffic because these operations may cause soil compaction affecting the crop development. This study aimed to generate the load-bearing capacity models for a Red-Yellow Latosol and to determine through the use of these models the soil susceptibility to compaction of the coffee plantation due to the implantation time and the compaction caused by the machinery traffic on the traffic lines located at the top and bottom of the ground. This study was carried out in the EPAMIG Experimental Farm, located at Três Pontas, MG, in coffee plantations (Coffee arabica L.) with 2, 7, 18 and 33 years of establishment. To obtain the load-bearing capacity models, 12 undisturbed soil samples were randomly collected in the $0-3 \mathrm{~cm}$ and $15-18 \mathrm{~cm}$ layers in the position between the rows for each establishment time of the coffee plantation. It was also randomly collected 10 undisturbed soil samples for each establishment time of the coffee plantations along the tractor traffic lines located at the top and bottom of the ground. These undisturbed soil samples were used in the uniaxial compression tests. The use of the load-bearing capacity models allow to identify the soil susceptibility to compaction due to the implementation time of the coffee plantation and the compaction caused by the machinery traffic on the traffic lines located at the top and bottom of the ground. The percentage of compacted soil samples increases with the establishment time in the layer of $15-18 \mathrm{~cm}$.
\end{abstract}

Index terms: Precompression stress, structure degradation, soil physics.

\section{RESUMO}

A principal fonte de degradação da estrutura do solo na exploração cafeeira é o tráfego de máquinas, pois essas operações podem causar compactação do solo, afetando o desenvolvimento da cultura. Neste estudo, objetivou-se gerar os modelos de capacidade de suporte de carga para um Latossolo Vermelho-Amarelo e determinar por meio do uso desses modelos a suscetibilidade à compactação do solo, pelo tempo de implantação da lavoura cafeeira e os impactos causados pelo tráfego das operações mecanizadas nas linhas de tráfego localizadas na parte de cima e de baixo do terreno. Este estudo foi realizado na Fazenda Experimental da EPAMIG, situada em Três Pontas, MG, em lavouras cafeeiras (Coffee arabica L.) com 2, 7, 18 e 33 anos de implantação. Para a obtenção dos modelos de capacidade de suporte de carga, 12 amostras indeformadas de solo foram coletadas aleatoriamente nas camadas 0-3 e 15-18 cm no centro das entrelinhas, para cada tempo de implantação da lavoura cafeeira. Foram também coletadas aleatoriamente 10 amostras indeformadas para cada tempo de implantação da lavoura cafeeira ao longo das linhas de tráfego do trator situadas nas partes de cima e de baixo do terreno. Essas amostras foram usadas no ensaio de compressão uniaxial. O uso dos modelos de capacidade de suporte de carga permitiu identificar a suscetibilidade do solo à compactação, em razão do tempo de implantação da lavoura cafeeira e a compactação causada pelo tráfego do maquinário nas linhas de tráfego situadas na parte de cima e de baixo do terreno. A porcentagem de amostras compactadas aumentou com a idade da lavoura na camada de $15-18 \mathrm{~cm}$.

Termos para indexação: Pressão de pré-consolidação, degradação da estrutura, física do solo.

(Received in april 24, 2012 and approved in june 19, 2012)

\section{INTRODUCTION}

The coffee culture was introduced in Brazil in 1727 and throughout its history had booms and crises in accordance with changes in the global economy (ORMOND, PAULA; FILHO, 1999). However, due to adaptation of the coffee plants to the soil conditions and climate, and also by increasing the plant area (INSTITUTO AGRONÔMICO DE CAMPINAS - IAC,
2011), today Brazil is the first producer and the second world consumer of the product (ASSOCIAÇÃO BRASILEIRADA INDÚSTRIA DE CAFÉ-ABIC, 2010). Currently, domestic production accounts for $39.6 \%$ of the world production, reaching in 2010/2011 a production of 39 million bags of $60 \mathrm{~kg}$ (ANÚARIO DA AGRICULTURA BRASILEIRA - AGRIANUAL, 2010), being the main producing states Minas Gerais, Espírito

1Universidade Federal de Lavras/UFLA - Departamento de Ciência do Solo/DCS - Lavras - MG - Brasil

2Universidade Federal de Lavras/UFLA-Departamento de Ciência do Solo/DCS - Cx. P. 3037-37.200-000 - Lavras - MG - Brasil - msouzadj@dcs.ufla.br ${ }^{3}$ Universidade Federal de Lavras/UFLA - Unidade Regional EPAMIG Sul de Minas - Lavras - MG - Brasil 
Santo, São Paulo and Paraná (MORAGADO, 2008; SANTOS et al., 2010).

Among the technologies used to promote the development of the coffee culture we can cite the mechanization (SANTOS et al., 2010). However, the intensive and indiscriminate use of the mechanization in the soils cultivated with coffee has changed the soil structure, promoting compaction over the years (ARAUJOJUNIOR et al., 2011a,b; GONTIJO et al., 2008; SANTOS et al. 2009; SANTOS et al., 2010) affecting the growth and longevity of coffee plants due to the changes in the environment where the root system develops (ARAUJOJUNIOR et al., 2011b), making the plants more susceptible to dry spells by altering the water flow, promoting inadequate aeration and nutritional deficiency and high soil mechanical strength which may limit root growth (ARAUJO JUNIOR et al., 2011a,b).

Soil compaction can be assessed using various soil physics properties such as bulk density, total porosity, penetration resistance, hydraulic conductivity (DIAS JUNIOR; PIERCE, 1996) and, from 1999 (KONDO; DIAS JUNIOR, 1999) the precompression stress began to be used to assess the soil compaction. Currently, the use of the precompression stress to evaluate the soil compaction is well documented in the literature (AJAYI et al., 2009; ARAUJO JUNIOR et al., 2011a,b).

To minimize the risk of soil compaction occurs, the machinery traffic should be done considering the precompression stress, which is a measure of the loadbearing capacity of the soil (DIAS JUNIOR et al., 2005). Moreover, the determination of the variations in the precompression stress as a function of soil water content can help to schedule the machinery traffic to prevent soil compaction (SANTOS et al., 2010).

Considering that the precompression stress is the maximum pressure that should be applied to the soil in order to avoid soil compaction and the criteria proposed by Dias Junior et al. (2005), this study aimed to generate the load-bearing capacity models for a Red-Yellow Latosol (Oxisol) and to determine through the use of these models the susceptibility to compaction of the coffee plantation due to the establishment time and the compaction caused by the machinery traffic on the traffic lines located at the top and bottom of the ground.

\section{MATERIALS AND METHODS}

This study was carried out at the Experimental Farm of EPAMIG (Empresa de Pesquisa Agropecuaria de Minas Gerais), located at Três Pontas, South of Minas
Gerais State, latitude $21^{\circ} 22^{\prime} 01^{\prime \prime} \mathrm{S}$ and longitude $45^{\circ} 30^{\prime}$ $46^{\prime \prime} \mathrm{W}$ of Green wich and average altitude of $905 \mathrm{~m}$. The climate is tropical of altitude Cwa according to the Köppen classification with a mean annual temperature of $19^{\circ} \mathrm{C}$. The total annual precipitation range from 1,400 to $1,700 \mathrm{~mm}$.

The soil of the study area was classified as a RedYellow Latosol (Oxisol) loamy texture (EMPRESA BRASILEIRA DE PESQUISA AGROPECUÁRIA EMBRAPA, 2006) with $490 \mathrm{~g} \mathrm{~kg}^{-1}$ of clay, $290 \mathrm{~g} \mathrm{~kg}^{-1}$ of silt and $220 \mathrm{~g} \mathrm{~kg}^{-1}$ of sand.

This study was conducted in coffee plantations with 2 (spacing $3.5 \mathrm{~m}$ x $0.7 \mathrm{~m}$ - Cultivate Mundo Novo), 7 (spacing $3.5 \mathrm{~m}$ x $0.9 \mathrm{~m}$-Cultivate Paraíso MG), 18 (spacing $3.5 \mathrm{~m} \times 1.0 \mathrm{~m}$-Cultivate Mundo Novo) and 33 (spacing 3.5 m x $2.0 \mathrm{~m}$ - Cultivate Catuaí Amarelo) years of establishment. According to the area history prior to the installation of the coffee plantations, the soil was plowed to a $40 \mathrm{~cm}$ deep and then harrowed.

All equipment used in the coffee crop management were pulled by a Massey Ferguson 265 tractor, with a mass of about $3,940 \mathrm{~kg}$ in which it were engaged the following equipment: fertilizer miname with approximate mass of $210 \mathrm{~kg}$ ( 3 passes per year), spray jet Arbus 400 Jacto with 400 L capacity and mass of 230 $\mathrm{kg}$ (3 passes per year), mower Kamaq with a mass of 340 $\mathrm{kg}$ ( 3 passes per year) and the spray jet $\mathrm{PH} 400$ with 400 $\mathrm{L}$ capacity and mass of $210 \mathrm{~kg}$ ( 2 passes per year). The total number of passes per year is equal to 11 times in the same traffic line for each plot at different establishment times.

To obtain the load-bearing capacity models which are the relationship between the precompression stress and the volumetric water content, 12 undisturbed soil samples of $6.4 \mathrm{~cm}$ in diameter and $2.54 \mathrm{~cm}$ height were collected randomly between the rows in the $0-3 \mathrm{~cm}$ and 15 $18 \mathrm{~cm}$ layers, for each plot cultivated with coffee by $2,7,18$ and 33 years totaling 96 undisturbed soil samples (12 undisturbed soil samples x 2 layers x 4 ages). These undisturbed soil samples were collected in 2010 in plots with a slope of 0-3\%.

These undisturbed soil samples were initially saturated in a pan with water to $2 / 3$ of the soil samples height for 24 hours, and then they were air-dried in the laboratory until the volumetric water content was found in the range of 0.05 to $0.42 \mathrm{~m}^{3} \mathrm{~m}^{-3}$, and then used in uniaxial compression test (BOWLES, 1986).

To performer the uniaxial compression tests, the undisturbed soil samples were kept inside the aluminum cylinders, which were placed inside the compression cell 
and subject to the pressures of 25, 50, 100, 200, 400, 800 and $1,600 \mathrm{kPa}$. Each pressure was applied until $90 \%$ of the maximum deformation was reached, and then the pressure was increased to the next level (TAYLOR, 1948). After releasing the pressure the soil samples were dried at $105-110^{\circ} \mathrm{C}$ for 24 hours and the dry mass and bulk density (BLAKE; HARTGE, 1986) were determined. From the soil compression curves, the precompression stresses $\left(\sigma_{\mathrm{p}}\right)$ were determined as a function of the volumetric water contents ( $\theta$ ) (DIAS JUNIOR; PIERCE, 1995). Then, the regression analyses were performed using the Sigma Plot software (Jandel Scientific, PO Box 7005, San Rafael, CA, USA), to obtain the load-bearing capacity model, which is the adjustment of $\sigma_{p}$ as a function of $\theta$. After that, the comparisons of the regression equations were made using the procedure described in Snedecor and Cochran (1989). For each condition in which the load-bearing capacity models were homogeneous, and the linear (a) and the angular (b) coefficients were not statistically different, the values of $\sigma_{p}$ and $\theta$ were grouped and a new equations were adjusted considering all these values. However, when the load-bearing capacity models were homogeneous, but the linear (a) and/or angular (b) coefficients differed significantly the values of $\sigma_{p}$ and $\theta$ were not grouped.

To determine the compaction caused by the machinery used in the coffee crop management over time, 10 undisturbed soil samples similar to those described above were collected randomly along the traffic lines located at the top and bottom of the ground totaling 160 soil samples ( 10 undisturbed soil samples $\mathrm{x} 4$ ages $\mathrm{x} 2$ layers $\mathrm{x} 2$ positions).

These undisturbed soil samples were subjected to the uniaxial compression test, as mentioned earlier, with the volumetric water content in which the mechanized operations were performed. After the performance of these tests, the $\sigma_{\mathrm{p}}$ were obtained according Dias Junior and Pierce (1995) and then represented in the load-bearing capacity models developed in this study as a function of the $\theta$ and using the criteria proposed by Dias Junior et al. (2005) the percentage of compacted soil samples were determined which allowed us to quantify the compaction caused by the machinery traffic on the traffic lines located at the top and bottom of the ground.

\section{RESULTS AND DISCUSSION}

The homogeneity tests of the load-bearing capacity models performed according to the procedure described in Snedecor and Cochran (1989) indicated homogeneity in some conditions and no significance of the linear (a) and angular (b) coefficients (Tables 1 and 2 ). For each one of these conditions the $\sigma_{p}$ and $\theta$ were grouped and a new equation was then adjusted considering all these values obtaining a single model (Tables 1 and 2 and figure 1). This non-significance between the models indicates that the conditions analyzed have the same ability to withstand loads. However, in other conditions the load-bearing capacity models were homogeneous, but the linear (a) and/or angular (b) coefficients differed significantly (Tables 1 and 2 and figure 1), indicating different load-bearing capacities and because of this $\sigma_{p}$ and $\theta$ were not grouped.

The load-bearing capacity models were of the type $\sigma p=10^{(a+b \theta)}$ (ARAUJO JUNIOR et al., 2011a), with R ${ }^{2}$ significant at $1 \%$. The estimated "a" and "b" values varied from 2.67 to 2.91 , and from -0.85 to -2.22 , respectively (Figures 1 and 2).

The 15-18 cm layer of the coffee with 2 years of establishment had a higher load-bearing capacity than the $0-3 \mathrm{~cm}$ layer for volumetric water content less than $0.26 \mathrm{~m}^{3}$ $\mathrm{m}^{-3}$. For volumetric water content higher than $0.26 \mathrm{~m}^{3} \mathrm{~m}^{-3}$, the $0-3 \mathrm{~cm}$ layer had higher load-bearing capacity than the $15-18 \mathrm{~cm}$ layer (Figure 1a). These results agree with Santos et al. (2010) who found similar results for the position between the rows in a coffee plantation subjected to weed control without weeding in a Red-Yellow Latosol.

Table 1 - Comparison of load-bearing capacity models in the $0-3 \mathrm{~cm}$ and $15-18 \mathrm{~cm}$ layers for the coffee culture with different establishment times in a Red-Yellow Latosol according to the procedure described in Snedecor and Cochran (1989).

\begin{tabular}{ccccc}
\hline Plot & $\mathrm{F}$ & Linear coefficient "a" & Angular coefficient "b" & Action \\
\hline 11B-2 years: $0-3 \times 15-18 \mathrm{~cm}$ & $\mathrm{H}$ & $\mathrm{ns}$ & $* *$ & Do not group \\
6BE-7 years: $0-3 \times 15-18 \mathrm{~cm}$ & $\mathrm{H}$ & $\mathrm{ns}$ & $*$ & Do not group \\
8B-18 years: $0-3 \times 15-18 \mathrm{~cm}$ & $\mathrm{H}$ & $\mathrm{ns}$ & $\mathrm{ns}$ & Group \\
7A-33 years: $0-3 \times 15-18 \mathrm{~cm}$ & $\mathrm{H}$ & $\mathrm{ns}$ & $\mathrm{ns}$ & Group \\
\hline
\end{tabular}

$\mathrm{H}=$ homogeneous; $*$ significant at $5 \% ; * *$ significant at $1 \% ; \mathrm{ns}=$ not significant. 
Table 2 - Comparison of the load-bearing capacity models in the $0-3 \mathrm{~cm}$ or in the $15-18 \mathrm{~cm}$ layers for the coffee culture with different establishment times in a Red-Yellow Latosol according to the procedure described in Snedecor and Cochran (1989).

\begin{tabular}{|c|c|c|c|c|}
\hline Plots & $\mathrm{F}$ & $\begin{array}{c}\text { Linear } \\
\text { coefficient "a" }\end{array}$ & $\begin{array}{c}\text { Angular } \\
\text { coefficient "b" }\end{array}$ & Procedure \\
\hline \multicolumn{5}{|c|}{$0-3 \mathrm{~cm}$} \\
\hline $11 \mathrm{~B}-2$ years $\mathrm{x} 6 \mathrm{BE}-7$ years & $\mathrm{H}$ & $* *$ & $* *$ & Do not group \\
\hline 11B-2 years $x$ 8B-18 years & $\mathrm{H}$ & $* *$ & $*$ & Do not group \\
\hline $11 \mathrm{~B}-2$ years $\mathrm{x} 7 \mathrm{~A}-33$ years & $\mathrm{H}$ & $* *$ & $* *$ & Do not group \\
\hline $6 \mathrm{BE}-7$ years $\mathrm{x} 8 \mathrm{~B}-18$ years & $\mathrm{H}$ & ns & ns & Group \\
\hline $6 \mathrm{BE}-7$ years and $8 \mathrm{~B}-18$ years $\mathrm{x}$ 7A-33 years & $\mathrm{H}$ & ns & ns & Group \\
\hline $6 \mathrm{BE}-7$ years, $8 \mathrm{~B}-18$ years and $7 \mathrm{~A}-33$ years $\mathrm{x} 11 \mathrm{~B}-2$ years & $\mathrm{H}$ & $* *$ & $* *$ & Do not group \\
\hline \multicolumn{5}{|l|}{$15-18 \mathrm{~cm}$} \\
\hline $11 \mathrm{~B}-2$ years $\mathrm{x} 6 \mathrm{BE}-7$ years & $\mathrm{H}$ & $*$ & ns & Do not group \\
\hline $11 \mathrm{~B}-2$ years $\mathrm{x} 8 \mathrm{~B}-18$ years & $\mathrm{H}$ & $*$ & ns & Do not group \\
\hline $11 \mathrm{~B}-2$ years $\mathrm{x} 7 \mathrm{~A}-33$ years & $\mathrm{H}$ & $* *$ & $* *$ & Do not group \\
\hline $6 \mathrm{BE}-7$ years $\mathrm{x} 8 \mathrm{~B}-18$ years & $\mathrm{H}$ & ns & ns & Group \\
\hline $6 \mathrm{BE}-7$ years and $8 \mathrm{~B}-18$ years $\mathrm{x}$ 7A-33 years & $\mathrm{H}$ & ns & ns & Group \\
\hline $6 \mathrm{BE}-7$ years, $8 \mathrm{~B}-18$ years and $7 \mathrm{~A}-33$ years $\mathrm{x} 11 \mathrm{~B}-2$ years & $\mathrm{H}$ & $* *$ & ns & Do not group \\
\hline
\end{tabular}

$\mathrm{H}=$ homogeneous; $*$ significant at $5 \% ; * *$ significant at $1 \% ; \mathrm{ns}=$ not significant.

The $15-18 \mathrm{~cm}$ layer of the coffee with 7 years of establishment had a higher load-bearing capacity for any volumetric water content than the 0-3 cm layer (Figure 1b). These results agree with Santos et al. (2009) and Araujo-Junior et al. (2011a) who found a greater load-bearing capacity for the $10-13 \mathrm{~cm}$ layer for the position between the rows in a coffee plantation subjected to weed control without weeding in a RedYellow Latosol and in a dystroferric Red Latosol, respectively. The higher load-bearing capacity indicates a greater resistance to compaction, however, this layer may offers greater resistance to the roots penetration (ARAUJO-JUNIOR et al., 2011b, MIRANDA et al., 2003a, b).

The 0-3 cm and $15-18 \mathrm{~cm}$ layers of the coffee with 18 and 33 years of establishment (Figures 1c and $1 \mathrm{~d}$, respectively) were not statistically different indicating a equilibrium of its load-bearing capacity (MIRANDA et al., 2003a,b) which did not occur with the coffee with 2 and 7 years of establishment. The homogenization of the load-bearing capacities of these layers is an indicative of the natural structure recovery of the $15-18 \mathrm{~cm}$ layer in relation to the $0-3 \mathrm{~cm}$ layer. These results agree with the results of Araujo-Junior et al. (2011a); Miranda et al. (2003a) and Santos et al. (2009).

The $0-3 \mathrm{~cm}$ layer of the coffee with 7, 18 and 33 years of establishment had higher load-bearing capacity than the $0-3 \mathrm{~cm}$ layer for the coffee with 2 years of establishment for volumetric water content lower than $0.18 \mathrm{~m}^{3} \mathrm{~m}^{-3}$. For volumetric water content higher than 0.18 $\mathrm{m}^{3} \mathrm{~m}^{-3}$ the $0-3 \mathrm{~cm}$ layer of the coffee with 2 years of establishment had greater load-bearing capacity than the other coffee plantations (Figure 2a).

The 15-18 cm layer of the coffee with 7, 18 and 33 years of establishment showed a lower load-bearing capacity for any volumetric water content than the 0-3 $\mathrm{cm}$ layer for the coffee with 2 years of establishment (Figure 2b). These results agree with the results obtained by Miranda et al. (2003b) who found for a Red Latosol cultivated with coffee that the coffee plants with longer establishment time had, in generally, lower load-bearing capacity. A lower load-bearing capacity indicates that the soil is more susceptible to soil compaction and less restrictive to the root system development (ARAUJO-JUNIOR et al., 2008, ARAUJOJUNIOR et al., 2011a,b, SANTOS et al., 2009, SANTOS et al., 2010). 

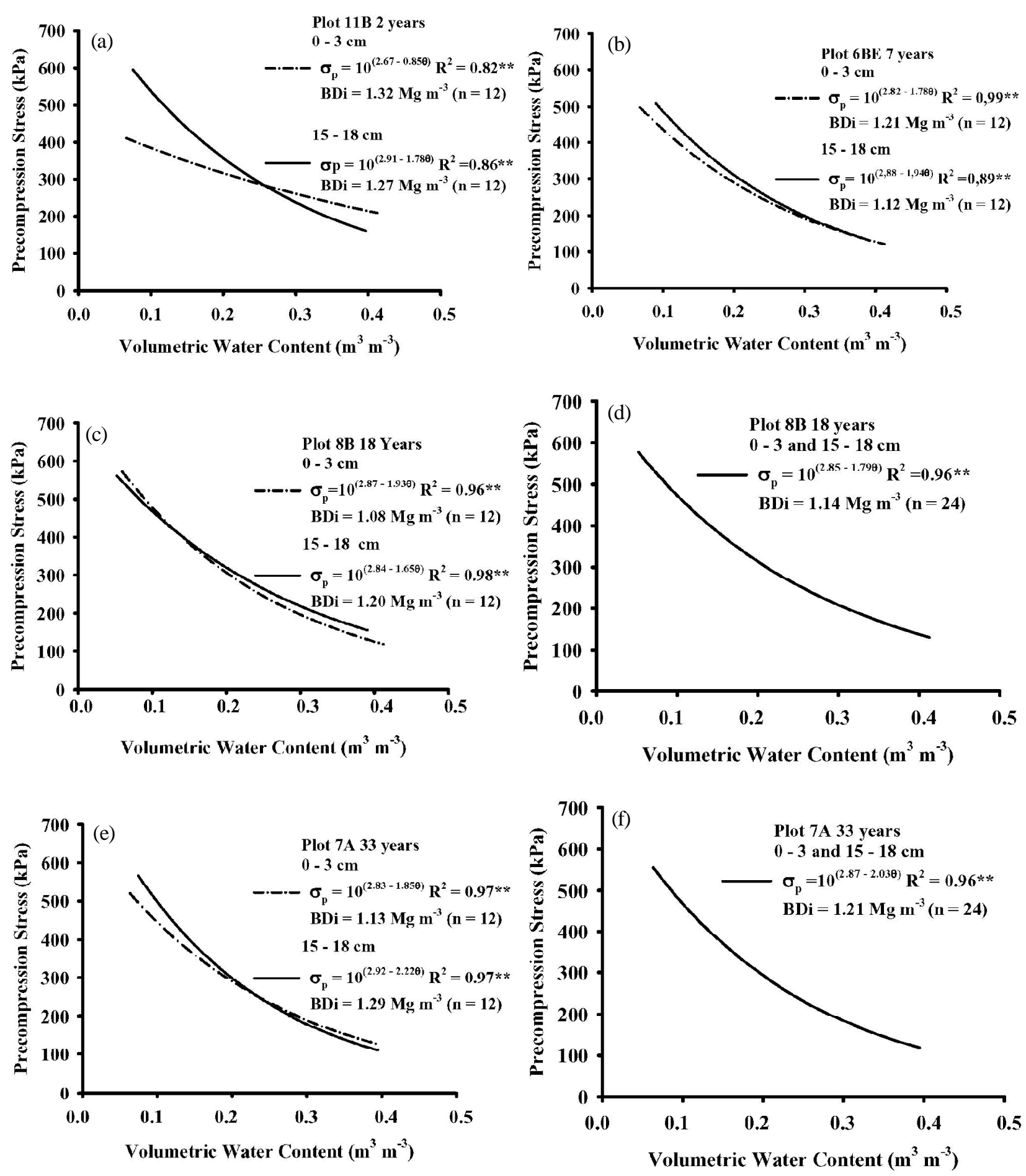

Figure 1 - Load-bearing capacity models of a Red-Yellow Latosol, for the position between the rows, for the coffee plots with different time of establishments. 

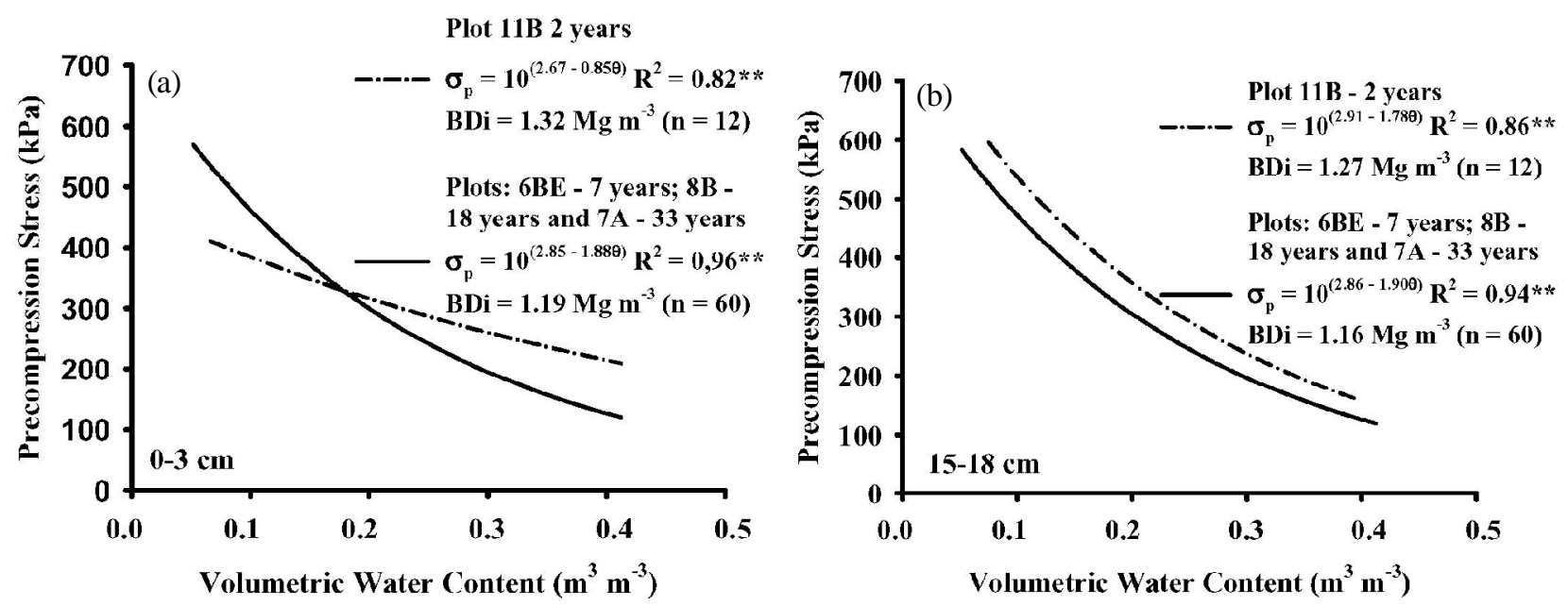

Figure 2 - Load-bearing capacity models of a Red-Yellow Latosol, for the position between the rows, for the coffee plots with different time of establishments.

The $0-3 \mathrm{~cm}$ layer of the coffee with $2,7,18$ and 33 years of establishment suffer higher compaction than the $15-18 \mathrm{~cm}$ layer (Table 3 ). These results agree with the results obtained by Dias Junior et al. (2008) who found more compaction caused by the mechanical operations in the 0 $3 \mathrm{~cm}$ layer. However, these results disagree with the results obtained by Santos et al. (2010) who found higher compaction in the $10-13 \mathrm{~cm}$ layer than in the 0-3 cm layer for the rotary tiller. Moreover, Silva, Dias Junior and Leite (2011) did not found a specific layer where soil compaction had occurred; therefore the results obtained by this researcher either indicated greater compaction in the 0-3 $\mathrm{cm}$ layer or in the $10-13 \mathrm{~cm}$ layer. Therefore, these finds do not permit to infer in which soil layer the compaction will occur demonstrating the importance of conducting studies for each specific condition and showing the impossibility of the results generalization in studies of soil compaction.

The compaction that occurred on the traffic line located at the bottom of the ground was equal or greater than the compaction that occurred in the traffic line located at the top of the ground (Table 3 ). The lower compaction that occurred in the $0-3 \mathrm{~cm}$ and in the $15-18 \mathrm{~cm}$ layers of the coffee with 2 years of establishment was due to the higher load-bearing capacity of the $0-3 \mathrm{~cm}$ layer for volumetric water content higher than $0.18 \mathrm{~m}^{3} \mathrm{~m}^{-3}$ and in any volumetric water content for the $15-18 \mathrm{~cm}$ layer compared with the others establishment times used in this study (Figure 2). These results suggest that in future studies of soil compaction conducted in regions with different slopes one should consider separately the traffic lines located at the top and bottom of the ground to better quantify the effects of compaction in the soil structure.

Table 3 - Percentage of compacted soil samples caused by mechanized operations on a Red-Yellow Latosol in the 0-3 and 15-18 cm layers according to the criteria proposed by Dias Junior et al. (2005).

\begin{tabular}{ccc}
\hline Plot & Traffic line & $\begin{array}{c}\text { Compacted soil } \\
\text { samples }(\%)\end{array}$ \\
\hline \multirow{2}{*}{ 11B-2 years } & $0-3 \mathrm{~cm}$ & \\
& top & 10 \\
6BE-7 years & bottom & 10 \\
& top & 60 \\
8B-18 years & bottom & 100 \\
& top & 70 \\
7A-33 years & bottom & 70 \\
& bottom & 50 \\
& 15-18 cm & 100 \\
\hline \multirow{2}{*}{ 11B-2 years } & top & 0 \\
& bottom & 0 \\
6BE-7 years & top & 0 \\
& bottom & 10 \\
8B-18 years & top & 10 \\
& bottom & 40 \\
7A-33 years & top & 50 \\
& bottom & 80 \\
\hline
\end{tabular}




\section{CONCLUSIONS}

The use of the load-bearing capacity models allowed identifying the soil susceptibility to compaction due to the establishment time of the coffee plantation and the compaction caused by the machinery traffic on the traffic lines located at the top and bottom of the ground.

The percentage of compacted soil samples increases with the establishment time in the layer of $15-18 \mathrm{~cm}$.

\section{ACKNOWLEDGEMENTS}

The authors would like to thank the Fapemig, CNPq, Capes, Embrapa Café and Epamig for funding this work.

\section{REFERENCES}

AJAYI, A.E. et al. Strength attributes and compaction susceptibility of Brazilian Latosols. Soil Tillage

Research, Amsterdam, v.105, n.2, p122-127, sept. 2009.

\section{ANUÁRIO DAAGRICULTURA BRASILEIRA- AGRIANUAL. Mercados e perspectivas do café. São Paulo: FNP, 2011. p. 192-210.}

ARAUJO JUNIOR, C.F. et al. Capacidade de suporte de carga e umidade crítica de um Latossolo induzida por diferentes manejos. Revista Brasileira de Ciência do Solo, Viçosa, v.35, n.1, p.115-131, jan./fev. 2011a.

ARAUJO JUNIOR, C.F. et al. Sistema poroso e capacidade de retenção de água em Latossolo submetido a diferentes manejos de plantas invasoras em uma lavoura cafeeira. Planta Daninha, Viçosa, v.29, n.3, p.499-513, jul./set. 2011 b.

ARAUJO JUNIOR, C.F. et al. Resistência à compactação de um Latossolo cultivado com cafeeiro, sob diferentes sistemas de manejo de plantas invasoras. Revista Brasileira de Ciência doSolo, Viçosa, v.32, n.1, p.25-32, jan./fev. 2008.

\section{ASSOCIAÇÃO BRASILEIRA DA INDÚSTRIA DE CAFÉ - ABIC. Indicadores da indústria de café no Brasil - 2009. Disponível em: <http://www.abic.com.br/ estatisticas $>$. Acesso em 16 out. 2010.}

BLAKE, G.R.; HARTGE, K.H. Bulk density. In: KLUTE, A. (Ed.). Methods of soil analysis. 2 ed. Madison, ASA/ SSSA. 1986. Part 1.p. 363-375.
BOWLES, J.E. Engineering properties of soils and their measurements. 3. ed. New York, McGraw Hill, 1986. $218 p$.

DIAS JUNIOR, M.S. et al. Traffic effects on the preconsolidation pressure due to eucalyptus harvest operations. Scientia Agricola, Piracicaba, v.62, n.3, p248255, maio/jun. 2005.

Assessment of the soil compaction of two Ultisols caused by logging operations. Revista Brasileira de Ciência do Solo, Viçosa, v. 32, n. 6, p.22452253, nov./dez. 2008.

DIAS JUNIOR, M.S.; PIERCE, F.J. A simple procedure for estimating preconsolidation pressure from soil compression curves. Soil Technology, Amsterdam, v.8, n.2, p.139-151, Nov. 1995.

Revisão de literatura: O processo de

compactação do solo e sua modelagem. Revista

Brasileira de Ciência do Solo, Campinas, v.20, n.1, p.175-182,jan./mar. 1996.

EMPRESA BRASILEIRA DE PESQUISA

AGROPECUÁRIA - EMBRAPA. Centro Nacional de

Pesquisas de Solos. Sistema brasileiro de classificação

de solos. 2. ed. Rio de Janeiro, Embrapa Solos, 2006. $306 \mathrm{p}$.

GONTIJO, I. et al. Atributos físico-hídricos de um Latossolo de Cerrado em diferentes posições de amostragem na lavoura cafeeira. Revista Brasileira de Ciência do Solo, Viçosa, v.32, n.6, p.2227-2234, Nov./dez. 2008.

INSTITUTO AGRONÔMICO DE CAMPINAS - IAC. Histórico. Disponível em <http://www.iac.sp.gov.br/ UniPesquisa/Cafe/Historico.asp>. Acesso em: 17 nov. 2011.

KONDO, M.K.; DIAS JUNIOR, M.S. Efeito do manejo e da umidade no comportamento compressivo de três latossolos. Revista Brasileira de Ciência do Solo, Viçosa, v.23, n.3, p.497-506, jul./set. 1999.

MIRANDA, E.É.V. et al. Modelos de sustentabilidade da estrutura de um Latossolo Vermelho cultivado com cafeeiros. Ciência e Agrotecnologia, Lavras, Edição Especial, p.1546-1553, 2003a. 
MIRANDA, E.É.V. et al. Efeito do manejo e do tráfego nos modelos de sustentabilidade da estrutura de um Latossolo Vermelho cultivado com cafeeiros. Ciência e Agrotecnologia, Lavras, Edição Especial, p.1506-1515, $2003 b$.

MORAGADO, A.A.M. Produção de café no Brasil - uma visão produção arábica e robusta. Revista Cafeicultura, Patrocínio, p. 1-5, dez. 2008. Disponível em: <http// www.revistacafeicultura.com.br/ índex.php?tipo=ler\&mat=25460 $>$. Acesso em: 11 jun. 2012.

ORMOND, J.GP.; PAULA, S.R.L.; FILHO, P.F. Café: (Re)conquista dos mercados. Rio de Janeiro: BNDES Setorial, 1999. 56p.

SANTOS, G.A. et al. Weed management and its influence on the load bearing capacity of Red-Yellow Latosol under the crown projection in coffee culture.
Coffee Science, Lavras, v.4, n.2, p.165-177, jul./dez. 2009.

SANTOS, G.A. et al. Suscetibilidade à compactação de um Latossolo Vermelho-Amarelo submetido a diferentes métodos de controle de plantas invasoras, na cultura cafeeira. Coffee Science, Lavras, v.5, n.2, p.123-136, maio/ago. 2010.

SILVA, A.R.; DIAS JUNIOR, M.S.; LEITE; F.P. Avaliação da intensidade de tráfego e carga de um forwarder sobre a compactação de um Latossolo Veremlho-Amarelo. Revista Árvore, Viçosa, v.35, n.3, p.547-554, maio/jun. 2011.

SNEDECOR, G. W.; COCHRAN, W. G Statistical methods. 8. ed. Ames: Iowa State University Press. 1989. $503 \mathrm{p}$.

TAYLOR, D. W. Fundamentals of soil mechanics. New York, John Wiley \& Sons, Inc., 1948, 700p. 